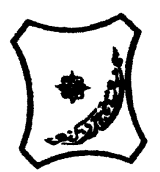

Bayero Journal of Pure and Applied Sciences, 8(1): 160 - 166

Received: June, 2015

Accepted: June, 2015

ISSN $2006-6996$

\title{
ECOLOGICAL RISK ASSESSMENT OF HEAVY METALS POLLUTION ON IRRIGATED SOIL ALONG SALANTA RIVER VALLEY, KANO STATE NIGERIA
}

\author{
${ }^{* 1}$ Mohammed, M. A., ${ }^{1}$ Yusuf, M.A., ${ }^{1}$ Mukhtar, S. and ${ }^{2}$ Zubairu, S.M. \\ ${ }^{1}$ Department of Geography Bayero University, Kano \\ ${ }^{2}$ Department of Geography Ahmadu Bello University Zaria, Nigeria \\ *Correspondence author: mansur_mhmmd@yahoo.com: +2348036032359
}

\begin{abstract}
This paper assessed the heavy metals pollution in irrigated soil of salanta river valley of Sharada industrial area with aim of assessing the potential ecological risk of $\mathrm{Cd}, \mathrm{Cu}, \mathrm{Cr}$ and $\mathrm{Zn}$. Soil samples were collected from five plots randomly selected along the stream and heavy metals (Cd, Cu, Cr and $\mathrm{Zn}$ ) and $\mathrm{pH}$ were analyzed using Atomic Absorption Spectrophotometer and pH meter respectively. The mean values and standard deviation of heavy metals in the study area shows that there is variation in the mean values among the heavy metal in the study area in which Cr recorded mean values of $2.30 \mathrm{mg} / \mathrm{kg} \pm 0.45, \mathrm{Cu} 1.01 \mathrm{mg} / \mathrm{kg} \pm 0.78, \mathrm{Cd} 3.02 \mathrm{mg} / \mathrm{kg} \pm 0.66, \mathrm{Zn} 26.4$ $\mathrm{mg} / \mathrm{kg} \pm 5.45$ and mean $\mathrm{pH} 6.8 \pm 0.51$. The $\mathrm{Cd}, \mathrm{Cu}$ and $\mathrm{Zn}$ were found below European regulatory values, the mean value of Cd $(3.02 \mathrm{mg} / \mathrm{kg}$ ) is found above EU regulatory values (3.0mg/kg) and the pH value of the study area shows that the soil is slightly acidic and can influence the availability and solubility of the heavy metals in the area. The assessment also show that $C d\left(P_{i j,}=\right.$ 1.0), $\mathrm{Cu}\left(P_{i j}=0.007\right)$ and $\mathrm{Zn}\left(P_{i j}=0.088\right)$ are heavily polluted the soil of the area, and also slight/y polluted with $\mathrm{Cr}\left(\boldsymbol{P}_{i j}=0.025\right)$. However, the potential ecological risk assessment show that $\mathrm{Cr}$ (Er $=0.005)$ and $\mathrm{Cu}\left(\mathrm{Er}^{j}=0.003\right)$ have low potential ecological risk in the area; $\mathrm{Zn}\left(\mathrm{Er}^{j}=0.04\right)$ has moderate potential ecological risk while $\mathrm{Cd}\left(\mathrm{Er}^{j}=0.088\right)$ is considerable potential ecological risk in the soil of study area. It was recommended that the industries should treat their waste water before discharge and farmers should avoid using waste water directly, sewage s/udge and effluent for watering and manure respectively.

Key words; Heavy metals, pollution, soil, ecological risk
\end{abstract}

\section{INTRODUCTION}

The term 'heavy metals' is often used to cover a diverse range of elements which constitute an important class of pollutants. Metals are considered heavy when their density is greater than 6 or 5

$\mathrm{Mgm}^{-3}$ (Wild, 1996). The presence of heavy metals in different foods constitute serious health hazard depending on their relative level e.g cadmium injures the kidney and cause symptoms of chronic toxicity including impaired kidney function, poor productive capacity, hypertension and tumor while chromium and copper in particular cause nephritis, anuria and extensive lesion in kidney (Ismail et al., 2006). Therefore, the problem of soil contamination by heavy metals is receiving global attention.

All the heavy metals except lead $(\mathrm{Pb})$ are transition element belonging to the $\mathrm{d}$ - Block in periodic table. Many of these element differ from the alkali earth metals (like. $\mathrm{Na}, \mathrm{Ca}$, and $\mathrm{Mg}$ ) in that they can exist in several valences state in soil. Heavy metals are markedly affected by soil redox potential and undergo both oxidation and redox depending on soil condition. This has important implications for the availability and toxicity of many heavy metals. For chromium $(\mathrm{Cr})$, oxidation converted to nontoxic $\mathrm{Cr}^{3+}$ ion to the toxic and carcinogenic $\mathrm{Cr}^{6+}$ ion. This reaction has even more significance in soils as a strongly precipitated cation $\left(\mathrm{Cr}^{3+}\right)$ is converted in to a poorly precipitate or soluble anion $\mathrm{CrO}_{4}{ }^{2-}$. The solubility and toxicity/availability to organisms of heavy metals cation $\left(\mathrm{Cd}^{2+}, \mathrm{Cr}^{3+}, \mathrm{Cu}^{2+}\right.$ and $\left.\mathrm{Zn}^{2+}\right)$ decrease as soil pH increases (Tailor and Francis, 2006).

The rapid population growth, industrialization and economic development of Kano metropolis necessitate people to use contaminated water including land and soil for irrigation activities to cater for the ever increasing population of the area. Heavy metals are continuously introduced to soil via several pathways including industrial activities, irrigation, fertilization, atmospheric deposition and point source where metals are produced as a result of refining and refinishing products (Mohammed, 2010).

Soils are usually regarded as the ultimate sink for heavy metals discharged in to the environment and can be sensitive indicators for monitoring contaminants (Nwachukwu et al., 2010). Therefore soil pollution by heavy metals has recorded increasing attention in the last few decades in both developing and developed countries throughout the world (Zhang et al., 2007). 
With the development of ecological survey, a great deal of data related to heavy metals concentration have being measured which can be used to assess the quality of ecological environment (Hakanson, 1980).

Several studies on the extent of heavy metals pollution on soil have been conducted (Yusuf et al., 2003; Ogbonna, 2006; Nwango et al., 2008; Olayiwola, 2011; Mohammed, 2010). However all these studies are limited in scope as they did not involve the potential ecological risk assessment of the pollutant in the area.

Generally, the monitoring and assessment of heavy metal concentrations in irrigated soils are required to evaluate the potential ecological risk of irrigated soils contaminated due to toxic heavy metals (Hang et al., 2009). Heavy metals are known to accumulate in living organisms. There is a tendency of plants to take up heavy metals that may subsequently transfer into the food chain. Use of polluted soil or water for crop cultivation mainly results in decrease of overall productivity and contaminates food grains and vegetables, which adversely affect human health too (Masironi et al., 1977).
Previous research conducted on concentrations of toxic metals in irrigated soil such as: Bada et al.,(2001); Dosumu (2003); Sorana, (2008); Abdulsalam (2009); Abechi et al., (2010); Nwachukwu et al,( 2010); and Abidemi (2013). However, such studies are very few in Kano metropolis, with little information on toxic heavy metal contamination of irrigated soil and potential ecological risk assessment. The objectives of this study, are primarily to assess the concentration of $\mathrm{Cr}$, $\mathrm{Cd}, \mathrm{Ni}$ and $\mathrm{Cu}$, assess the level of pollution by the individual heavy metals and evaluate the ecological risk of $\mathrm{Cr}$, $\mathrm{cd}, \mathrm{Ni}$ and $\mathrm{Cu}$ in the study area.

\section{MATERIALS AND METHODS}

\section{Study area}

The research was conducted in the irrigated soil along the banks of the streams of Salanta where the stream water were mostly from contaminated industrial effluents, waste water and sewage sludge from Sharada industrial areas, Latitude $11^{\circ} 57^{\prime} \mathrm{N}$ and $11^{\circ} 56^{`} \mathrm{~N}$ and Longitude $8^{\circ} 33^{\circ} \mathrm{E}$ and $8^{\circ} 36^{\circ} \mathrm{E}$ (figure 1) where the most common vegetables are grown such as onion, carrot, cabbage, lettuce and spinach (Field survey, 2014).

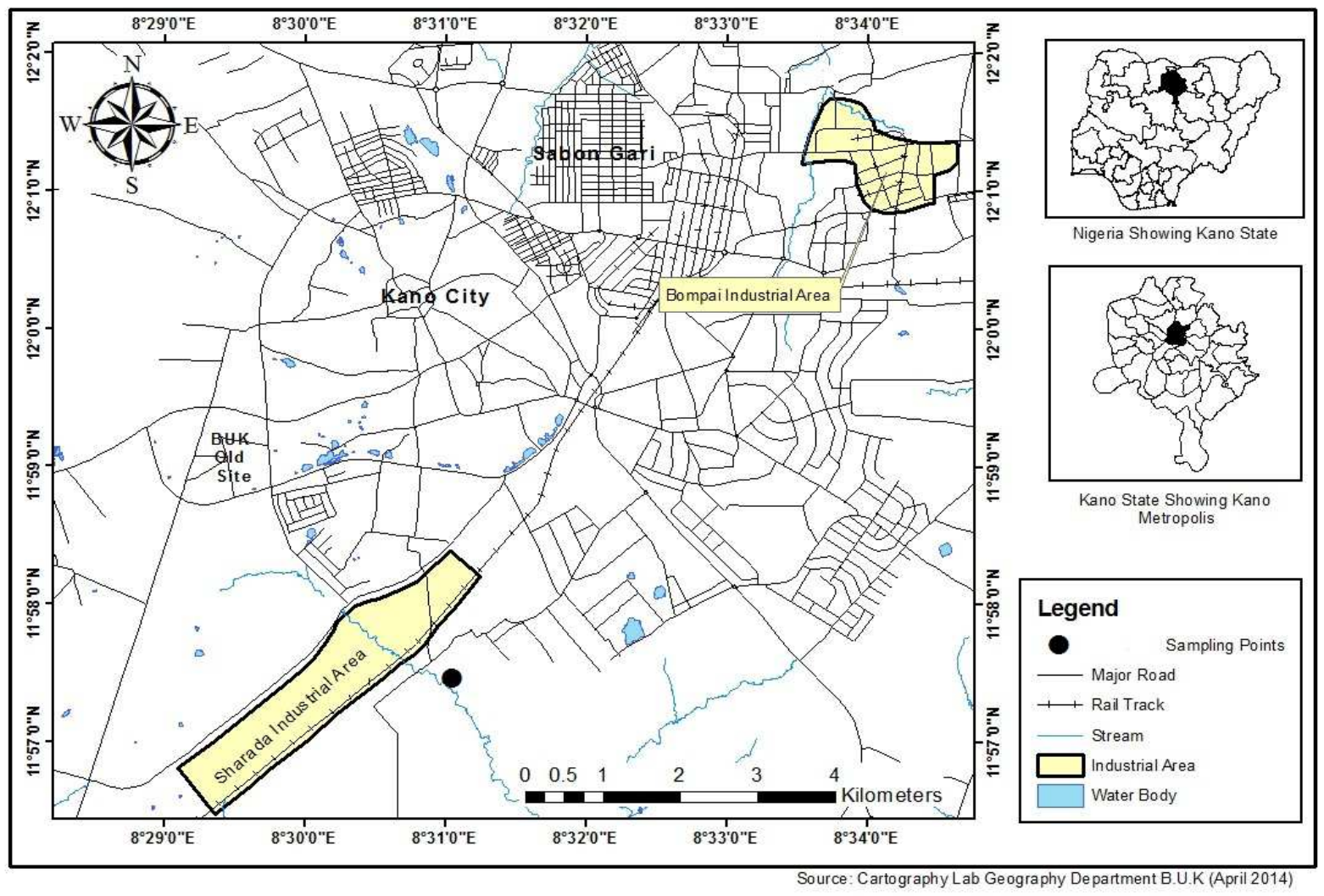

Figure 1: study area

The area fall within the basement complex and is about $500 \mathrm{~m}$ above mean sea level with little granite, few laterite outcrops and relatively plain (Olofin, 1987). The hydrology and drainage are influenced by rock structure, climate and human activities. The soil is well drained and is often fine sandy texture, sandy loam, very permeable and good for both rainfed and irrigation practice, hydromorphic soils also found in flooded area and have high content of clay. 


\section{Materials}

The materials used include global positioning system (GPS) for recording the coordinate; soil auger and spade used for taking the soil samples, $\mathrm{pH}$ meter was used in determine the $\mathrm{pH}$ value of the soil, Kjiedahl digestion set and Atomic absorption spectrophotometer to analyses the concentration of heavy metals under investigation.

\section{Collection of Samples}

Five irrigated plots along the stream of Salanta river valley were selected randomly for sampling the soil. Composite sampling method was used based on the assumption that each of the plot selected are homogeneous in term of soil type and factors influencing the accumulation of heavy metals. Soil auger was used to for sampling the soil from the depth of $0-20 \mathrm{~cm}$ thereby several soil samples were collected from different point in the same plot and then mixed vigorously and sub-sample (composite sample) of about half kilogram was taken and placed in polythene bags, labelled appropriately, and taken to laboratory, air dried, sift through $2 \mathrm{~mm}$ sieve and then waiting for further analysis.

\section{Sample Preparation}

The soil was digested through wet digestion method as recommended by Anderson (1974). Five gramme $(5 \mathrm{~g})$ of air dried, grounded and sieved soil was weighted in a clean $300 \mathrm{ml}$ calibrated digested tube and $5 \mathrm{ml}$ of concentrated sulpheric acid $\left(\mathrm{H}_{2} \mathrm{SO}_{4}\right)$ was added in the fume hood and swirled carefully and the tubes were placed in the tubes rack and then placed in the block-digester. Gradually, the temperature setting was increased from $60^{\circ} \mathrm{C}$ to $145^{\circ} \mathrm{C}$ for 1 hour. Five millilitre $(5 \mathrm{ml})$ tri-acid mixtures $\left(\mathrm{HNO}_{3}-\mathrm{H}_{2} \mathrm{SO}_{4}-\mathrm{HClO}_{4}\right)$ was added and then heated to $240^{\circ} \mathrm{C}$ for further 1 hour and kept overnight to avoid excessive foaming. The tubes rack was removed out of the block-digester and carefully placed on a rack holder and allowed to cool at room temperature and then filtered through whatman No. 42 filter papers and stored in pre - cleaned polythene bottles for further analysis and the digestion was done in triplicate and blank sample was also prepared.

\section{Instrumentation}

Atomic Absorption Spectrophotometer (210 VGP, American model) was used, the instrument was set up at a wavelength for each analyte. The flame was switched on and allowed to stabilize for about 10 minutes. Adjustment were made to achieve the most sensitive line for the metals that was analyzed. The digested sample was filtered and then aspirated, the results are dispensed on the read out unit of Atomic Absorption Spectrophotometer.

\section{POLLUTION ASSESSMENT CRITERIA} a). Pollution index (Pi) per metal

The single pollution index evaluation method is used to evaluate the level of selected heavy metals in the study area to obtain the real qualitative information of key pollutant element which is one of the most current methods used in evaluation of degree of heavy metals pollutant in soils (Hong-gui et a./, 2012).

$$
P_{i j}=\frac{C_{i j}}{S_{i j}}
$$

Where:-

$\mathrm{P}_{\mathrm{ij}}=$ pollution index of heavy metal $\mathrm{j}$ in the $\mathrm{j}-$ th functional area of soil.

$\mathbf{C}_{\mathbf{i j}}=$ is the measured contaminant value of heavy metal $j$ in the $j$-th functional area.

$\mathbf{S}_{\mathrm{ij}}=$ is the background contaminant value of heavy metal j.(Constant values)

The $\mathbf{S}_{\mathrm{ij}}$ values for heavy metals under investigation (As, $\mathrm{Cd}, \mathrm{Cr}, \mathrm{Cu}, \mathrm{Hg}, \mathrm{Ni}, \mathrm{Pb}$, and $\mathrm{Zn}$ ) were based on the European Union values specified in the European Union Standards for Soil Quality (Chen, 1998). According to the value of $\mathrm{P}_{\mathrm{ij}}$, we can determine the kind of pollutant and the most serious pollutant in the study areas.

Table 1: Evaluation grading standards of the single-factor index method

$\begin{array}{lllll}\text { Sub - index } & \mathbf{P}_{\mathrm{ij}}<\mathbf{0 . 0 0 1} & \mathbf{0 . 0 0 1} \leq \mathrm{P}_{\mathrm{ij}}<\mathbf{0 . 0 0 2} & \mathbf{0 . 0 0 2} \leq \mathbf{P}_{\mathrm{ij}}<0.003 & \mathbf{0 . 0 0 3} \leq \mathbf{P}_{\mathrm{ij}} \\ \text { Quality grade } & \text { Clean } & \text { Potential pollution } & \text { Slightly polluted } & \text { Heavily polluted }\end{array}$

Adopted from Cheng et al., 2007

\section{b). Contamination factor}

A contamination factor $\left(C_{f}^{i}\right)$ to describe the contamination of a given toxic heavy metals in a soil, lake or a sub basin as suggested by Hakanson (1980) as:-

$$
C_{f}^{i}=\frac{C_{0-1}^{i}}{C_{n}^{i}}
$$

Where:-

$C_{f}^{i}$ is the contamination factor

$C_{0-1}^{i}$ is the mean content of the metals $\boldsymbol{i}$

$C_{n}^{i}$ is the pre-industrial reference level for the metal

(Constant values, table 3 ).

Table 2: Contamination grading standard

\begin{tabular}{|c|c|l|c|c|}
\hline Sub - index & $\boldsymbol{C}_{\boldsymbol{f}}<\mathbf{0 . 0 0 1}$ & $\mathbf{0 . 0 0 1} \leq \boldsymbol{C}_{\boldsymbol{f}}<\mathbf{0 . 0 0 3}$ & $\mathbf{0 . 0 0 3} \leq \boldsymbol{C}_{\boldsymbol{r}}<\mathbf{0 . 0 0 6}$ & $\boldsymbol{C}_{\boldsymbol{f}} \geq \mathbf{0 . 0 0 6}$ \\
\hline $\begin{array}{c}\text { Contamination } \\
\text { grading standard }\end{array}$ & $\begin{array}{c}\text { Low } \\
\text { contamination } \\
\text { factor }\end{array}$ & $\begin{array}{l}\text { Moderate } \\
\text { contamination factor }\end{array}$ & $\begin{array}{c}\text { Considerable } \\
\text { contamination } \\
\text { factor }\end{array}$ & $\begin{array}{c}\text { very high } \\
\text { contamination } \\
\text { factor }\end{array}$ \\
\hline
\end{tabular}

Source Adopted from Hakason (1980) 


\section{Threshold values of some heavy metals}

The reference values used to assess the degree of pollution and potential ecological risk obtained either from the pre-industrial reference level, the average crust level, the background level, baseline, national criteria, threshold pollution value, and Sediment Quality Guidelines. However, this work adopted European Union threshold values.

Table 3: Threshold (EU) values and toxic level

\begin{tabular}{|l|c|r|r|r|}
\hline \multirow{2}{*}{} & \multicolumn{4}{|c|}{ heavy metals (Mg/kg) } \\
\cline { 2 - 5 } & Cd & Cu & Cr & Zn \\
\hline Pre-industrial level & 3 & 140 & 90 & 300 \\
\hline Toxic level & 0.03 & 0.14 & 18 & 0.3 \\
\hline
\end{tabular}

\section{Source: Adopted from CEC (1988) and Hakason (1980)}

\section{c). Ecological risk factor}

An ecological risk factor ( $E r$ ) to quantitatively express the potential ecological risk of a given contaminant, defined as:-

$\mathrm{Er}^{\mathrm{i}}=$ Ecological risk factor (Adapted from CEC, 1988; Hakason, 1980)
$\mathrm{Tr}^{\mathrm{i}}=$ is the toxic-response factor for a given metals $C_{f}^{i}$ is the contamination factor.

The $\operatorname{Tr}^{i}$ values of heavy metals given in the following terminologies are used to describe the risk factor.

Table 4. Grading ecological risk

\begin{tabular}{|c|c|c|c|c|c|}
\hline Sub - index & $E r^{i}<0.04$ & $0.04 \leq E r^{i}<0.08$ & $0.08 \leq E r^{i}<0.16$ & $0.16 \leq E r^{i}<0.32$ & $E r^{i} \geq 0.32$ \\
\hline $\begin{array}{l}\text { Grade } \\
\text { ecological risk }\end{array}$ & $\begin{array}{l}\text { low } \\
\text { potential } \\
\text { ecological } \\
\text { risk }\end{array}$ & $\begin{array}{l}\text { moderate potential } \\
\text { ecological risk }\end{array}$ & $\begin{array}{l}\text { considerable } \\
\text { potential } \\
\text { ecological risk }\end{array}$ & $\begin{array}{l}\text { high potential } \\
\text { ecological risk }\end{array}$ & $\begin{array}{l}\text { very high } \\
\text { ecological } \\
\text { risk }\end{array}$ \\
\hline
\end{tabular}

\section{Adopted from Hakason (1980)}

The risk factor is successfully used for assessing the quality of sediments and soils in environment by heavy metals. According to the soil quality standard issued by European Union (E.U), uses environmental quality index method to evaluate the quality of soil.

\section{RESULTS AND DISCUSSION}

The results obtained from the analyses of $\mathrm{Cd}, \mathrm{Cu}, \mathrm{Cr}$ and $\mathrm{Zn}$ are presented in Table 5 in which the mean values were compared with EU values single factor index and potential ecological risk of the selected metals are evaluate in this section.

\section{Table 5: Mean and Standard deviation of Heavy Metals with EU values}

\begin{tabular}{|l|l|c|c|}
\hline Heavy metals & Mean values $\mathbf{~ M g / k g ) ~}$ & Standard deviation & EU values \\
\hline $\mathrm{Cd}$ & 3 & \pm 0.45 & 3 \\
$\mathrm{Cu}$ & 1.01 & \pm 0.78 & 140 \\
$\mathrm{Cr}$ & 2.33 & \pm 0.66 & 180 \\
\hline $\mathrm{Zn}$ & 26.41 & \pm 5.48 & 300 \\
\hline Mean pH & 6.8 & \pm 0.51 &
\end{tabular}

Source: Lab, (2010) and CEC (1988)

Table 5, shows the mean concentration of heavy metal in the study area. The analysis of the heavy metals under investigation revealed that there is differences in the concentration of heavy metals in the area which could be attributed to the behavior of the individual metal in nature and in soil, as its related to the physical and chemical nature of the soils.

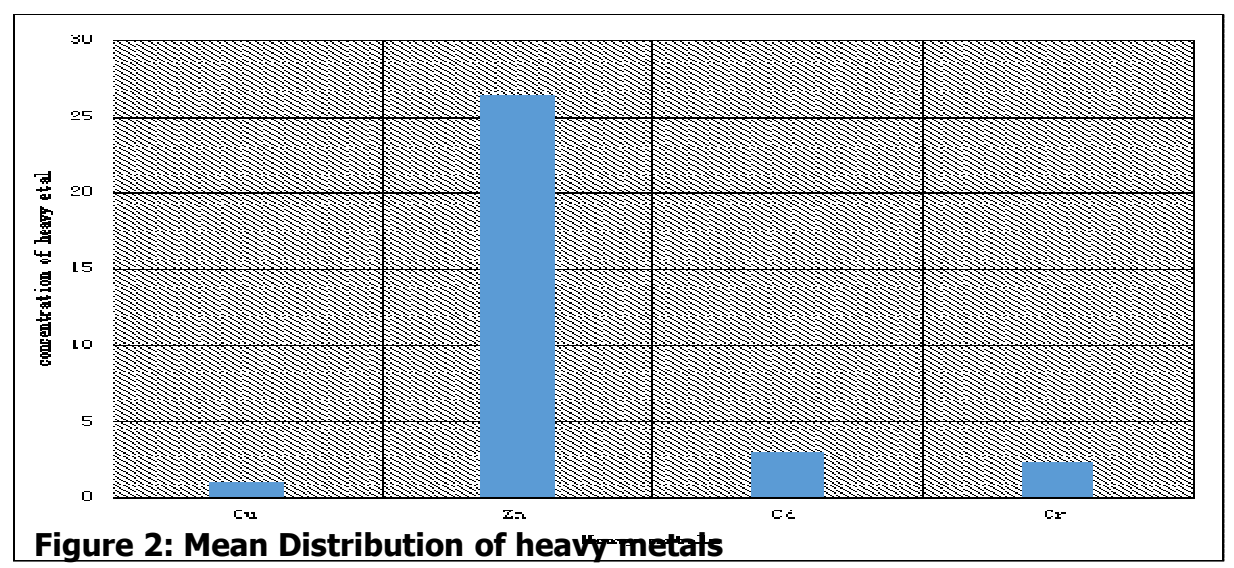


The distribution of heavy metals in the study area (Figure 2) shows that zinc have high mean value $(26.41 \mathrm{mg} / \mathrm{kg})$ while copper recorded low mean value $(1.01 \mathrm{mg} / / \mathrm{kg})$. This shows that some heavy metals are rare in nature and can be found in very low concentration but at high concentration they are strongly toxic and can pose an environmental threat (Tahar and Keltoum 2011). This is adduced by Brady and Weil (1999) that some heavy metals like cadmium is known to be rare in nature and required by plant and animal in minute quantity. The $\mathrm{pH}$ values of the study area (Table 5 ) indicated that the soil is acidic thereby absorption of heavy metals to plant/crops in the area depend on the soil $\mathrm{pH}$ values which is a key parameter controlling heavy metals transfer behavior in soil. The observed values in this study (6.8) may have implication on the availability and uptake of metals by plant grown in the area. This is contended by Francis and Tailor (2006) that the reaction of heavy metals in soil is definitely affected by $\mathrm{pH}$ in which $\mathrm{Zn}$ and $\mathrm{Cu}$ at $\mathrm{pH}$ value of 6.5 and above their availability and solubility to plant are low especially if they are present at their high valent or oxidized form. In strong acidic condition, however $\mathrm{Cr}$

\section{Single-factor index analysis}

Based on the grading standard of single pollution index (Table 6), the analyses of heavy metals under investigation shows that the single pollution index value for chromium $(0.025 \mathrm{mg} / \mathrm{kg})$ is slightly polluted while, cadmium $(1.0 \mathrm{mg} / \mathrm{kg})$, copper $(0.007 \mathrm{mg} / \mathrm{kg})$ and nickel $(0 . \mathrm{mg} / \mathrm{kg})$ are all within the values of is readily soluble with a low uptake by plant whereas it is readily available even at very low amount if retained by root.

Figure 3: mean values and threshold values proposed by EU

Comparison between mean values of heavy metals and European Union community regulatory values shows that (figure 2) all metal under investigation were found below EU regulatory values with exception of cadmium which have equal value with EU regulatory value. This shows that the level of heavy metals ( $\mathrm{Cu}, \mathrm{Zn}, \mathrm{Cd}$ and $\mathrm{Cr}$ ) does not reach the level that may cause any ecological risk.

\section{Evaluation of Degree of Pollution}

Single factor index analyses is used to find the level or extent of pollution by individual heavy metals under investigation, contamination factor also used in this study to evaluated the level of the contamination by heavy metals under investigation while potential ecological risk is also evaluated in the soil of the study area.

heavily polluted in quality grade standard (Table 6). This indicated that the soil have less concentration of chromium compared to other three heavy metals ( $\mathrm{Cd}$, $\mathrm{Cu}$ and $\mathrm{Ni}$ ). However, $\mathrm{Cd}, \mathrm{Cu}$ and $\mathrm{Ni}$ are pollutants with high contamination level among the heavy metals under investigation in irrigated soil of Salanta river valley

Table 6:The pollution index of each heavy metal in Salanta river valley

\begin{tabular}{|c|c|c|c|c|}
\hline \multirow{2}{*}{$\mathrm{Cij}$} & $\mathrm{Cr}$ & $\mathrm{Cd}$ & $\mathrm{Cu}$ & $\mathrm{Zn}$ \\
\cline { 2 - 5 } & 2.3 & 3 & 1.01 & 26.4 \\
\hline $\mathrm{Sij}$ & 90 & 3 & 140 & 300 \\
\hline $\mathrm{Pij}$ & 0.025 & 1 & 0.007 & 0.088 \\
\hline Quality grade & Slightely pollution & Heavily polluted & Heavily polluted & Heavily polluted \\
\hline
\end{tabular}

Source : Laboratory 2010

\section{Contamination factor}

The contamination factor $\left(\mathbf{C}_{\mathrm{f}}\right)$ (table 7$)$ shows that all the heavy metals $\mathrm{Cd}, \mathrm{Cr}$, $\mathrm{Cu}$ and $\mathrm{Ni}$ are graded within very high contamination factor in the sub - index (table 7). This indicates that all the heavy metals (Cd, $\mathrm{Cr}, \mathrm{Cu}$ and $\mathrm{Ni}$ ) contaminated the soil of the study area.

Table 7 : The contamination factor of each Heavy Metal in Salanta River valley

\begin{tabular}{|c|c|c|c|c|}
\hline \multirow{2}{*}{ Factors } & \multicolumn{4}{|c|}{ Heavy metal (mg / kg) } \\
\hline $\mathrm{C}_{\text {i0-1 }}$ & $\mathbf{C r}$ & $\mathbf{C d}$ & $\mathbf{C u}$ & $\mathbf{Z n}$ \\
\hline $\mathrm{C}_{\text {in }}$ & 90 & 2.98 & 1.05 & 26.4 \\
\hline $\mathrm{C}_{\text {if }}$ & 0.027 & 3 & 140 & 300 \\
\hline Quality grade & Very high contamination & $\begin{array}{c}\text { Very high } \\
\text { contamination }\end{array}$ & $\begin{array}{c}\text { Very high } \\
\text { contamination }\end{array}$ & $\begin{array}{c}\text { Very high } \\
\text { contamination }\end{array}$ \\
\hline
\end{tabular}

Source: Laboratory (2010) 


\section{Potential ecological risk}

The potential ecological risk values of chromium $(0.005 \mathrm{mg} / \mathrm{kg})$ and copper $(0.003 \mathrm{mg} / \mathrm{kg})$ fall within low potential ecological risk, and Zinc $(0.04 \mathrm{mg} / \mathrm{kg})$ is considered within moderately potential ecological risk while cadmium $(0.088 \mathrm{mg} / \mathrm{kg})$ is within considerable potential ecological ris. This indicated that Salanta irrigated site have low potential ecological risk with regard to chromium and copper thereby there is low potential risk pose by $\mathrm{Cr}$ and $\mathrm{Cu}$ because the low concentration in the soil of the area. However, cadmium is considered to have potential in ecological risk in the study area while zinc is moderate. Conclusively, zinc and cadmium are may pose some ecological risk in the area.

Table 8 : The potential ecological risk of each heavy metal in Salanta river valley (mg / kg)

\begin{tabular}{|c|c|c|c|c|}
\hline \multirow{2}{*}{ Tri } & \multicolumn{4}{|c|}{ Heavy metal } \\
\cline { 2 - 5 } & $\mathbf{C r}$ & $\mathbf{C d}$ & $\mathbf{C u}$ & $\mathbf{Z n}$ \\
\hline Cif & 0.18 & 0.03 & 0.14 & 0.3 \\
\hline Eri & 0.03 & 2.96 & 0.003 & 0.15 \\
\hline $\begin{array}{c}\text { Quality } \\
\text { grade }\end{array}$ & $\begin{array}{c}\text { Low potential } \\
\text { ecological risk }\end{array}$ & $\begin{array}{c}\text { considerable potential } \\
\text { ecological risk }\end{array}$ & $\begin{array}{c}\text { Low potential } \\
\text { ecological risk }\end{array}$ & $\begin{array}{c}\text { moderate potential } \\
\text { ecological risk }\end{array}$ \\
\hline
\end{tabular}

\section{Source: Laboratory (2010)}

\section{CONCLUSION AND RECOMMENDATION}

Considering the quality grading standard from single pollution index, contamination factor and potential ecological risk of the heavy metals found out that chromium, copper and nickel are all clean, does not reach the level that contaminate the soil and low potential ecological risk respectively, while cadmium was found is slightly polluted, moderately contaminated and have moderately potential ecological risk to the soil of the area.

\section{RECOMMENDATIONS}

Based on the results obtained from the assessment, the following were recommended in the areas.

1. Liming the soil to raise the $\mathrm{pH}$ because the heavy metals cations are the most soluble and available under acid condition, as $\mathrm{pH}$ is increased, the ionic forms of heavy metals cation are changed to the hydroxides or oxide.

\section{REFERENCES}

Abdulsalam, N. (2009); Assessment of Heavy Metals Pollution in Dump sites of Ilorin Metropolis. Ethiopian Journal of Environmental Studied and Management Vol.2 No. 2.

Abechi. E. S., Okunola, O. J., Zubairu, S. M.,1, A. A. Usman, A. A., and Apene, E. (2010): Evaluation of Heavy Metals in Road side Soil of Major Streets in Jos Metropolis, Nigeria. Journal of Environmental Chemistry and Ecotoxicology Vol. 2(6), pp. 98-102,

Abidemi, O. O., (2013): Accumulation and Contamination of Heavy Metals in Soil And Vegetation From Industrial Area of Ikirun, Osun State,Nigeria. Global Journal of Pure and Applied Chemistry Research, Vol.1, No.1 pp.25-34, June 2013 Published by E. C. R. T. and D, UK.
2. Biological method to remediate contaminated soils are getting prominent, certain plant should be planted over the contaminated areas especially Salix spp in particular this plant have the ability to absorb cadmium thereby reducing their concentration from the irrigated soils

3. Addition and or increase of organic matter to the soils which help to improve the water holding capacity of the soil, increase $\mathrm{pH}$ level and clay content, thereby reducing the need for frequent irrigation and reduce the solubility and availability of the heavy metals to the crops grown in the area.

4. Farmers should avoid direct use of the contaminated water for watering directly or using sludge as manure.

5. Tube wells and hand dug wells should be used as source of irrigation water to avoid used of contaminated water.

Anderson, J. (1974); Wet Digestion Versus Dry for the Analysis of Fish Tissue for Trace Metals; Afon Absorption newsletter.

Bada, S. B., Amusan, A .A and Salami, A.T (2002): Level of Some Metals in Soils And Vegetation Along Roadsides in Osun State: Nigeria; Journal of Agriculture and Environment 2(2)

Brady, N. C. and Weil Ray R. (1999): Nature and Properties of Soils; $10^{T H}$ Edition New York state collage of agriculture and life science cornell university, macmillan publisher co. $8663^{\text {rd }}$ Avenue, New York 10022.

CEC (1986): Commission of the European Communities Council Directive on the Protection of the Environment and in Particular of the Soil, when Sewage Sludge is Used in Agriculture. Official Journal of Environmental Comm. L181 6 
Cheng, J. L., Shi, Z and Zhu, Y. W. (2007): Assessment and Mapping of Environmental Quality in Agricultural Soil of Zhejian Province, China. Journal of Environmental Science. In Qingjie, G and Jun D. (2008) (Eds), Calculating Pollution Index by Heavy Metals in Ecological Geochemistry Assessment a Case Study of Park of Beigin. Journal of China University of Geosciences. Vol 19 (3).

Chen, Z. S (1998): Management of Contaminated Soil Remediation Programe. Land Contamination and Reclamation 6 41- 56

Dosumu, O. O., Salami, N. and Adekola, F. A. (2005): Comparative Study of Trace Element Levels. bull. Chem. Soc. Ethiop17 (1), $107-112$.

Francis and Tailor (2006): Encyclopedia of Soil Science, Second Edition Volume One and Two; Rattan Lal: The Ohio State University Colombus, Ohio, U.S.A. Newyork London. Pp $165-172$.

Hakanson, L.,(1980)An Ecological Risk Index for Aquatic Pollution Control: A Sedimentological Approach. Water Research, 14: 975-1001

Hang, X., H. Wang, H. J. Zhou, C. Ma, C. Du, and X. Chen, (2009)"Risk assessment of potentially toxic element pollution in soils and rice (Oryza sativa) in a typical area of the Yangtze River Delta," Environmental Pollution, vol. 157, no. 8-9, pp. 25422549,. View at Publisher - View at Google Scholar - View at Scopus.

Hong - gui, D. Teng - feng, D. U, Ming - hu L. I. and Xuxu, D. (2012): Comprehensive Assessment Model of Heavy Metal Pollution In Soil. International journal of Electro Chemical Science.

Ismail, K. Selda T.O, and Murat B. (2006), Fresemius. Environmental Bulletin 15(1), 26.

Logan T. J (2000) Soil and environmental quality. M.E., Ed.; CRC Press Boca Roton FL. Pp $67-69$.

McLaauhglin, M. J.; Zarcianas, B.A,; Stevens,D.P,; Cook, N. (2000); Soil Testing Metals. Commun. Soil science plant Anal.

Masironi, R., Koirtyohann, S. R. and. Pierce, J. O (1977) "Zinc, copper, cadmium and chromium in polished and unpolished rice," Science of the Total Environment, vol. 7, no. 1, pp. 27-43. View at Publisher - View at Google Scholar · View at Scopus
Mohammed, M.A., (2010): An Assessment Of Heavy Metals Pollution In Soils Under urban and Peri- Urban Irrigation in Kano Metropolis. Unpublished M.Sc Thesis, Geography Department, Bayero University KanoNigeria.

Nwachukwu, M. A.; Feng, H.; Alinnor, J., (2010): Assessment of Heavy Metal Pollution In Soil and their Implications Within And Around Mechanic Villages. International Journal of Environmental Science and Technology 7 (2), 347-358.

Nwaugo, V. O, Onyeagba, R. A., Akubugwu, E. I. and Ugbogu, O. (2008): Soil bacterial Flora and Enzymatic Activities in Zinc and Lead Contaminated Soil in Ishiagu, Abia State. An international Journal of Experimental Biology. BIOKEMISTRI 20(2):77-84.

Ogbonna, D. N. and Igbenijie, M. (2006): Characteristics of Microorganisms Associated with Waste Collection Sites in Port Harcourt City, Nigeria. Nigerian Journal of Microbiology 20(3):1427-1434.

Olayiwola, O. A. (2011): An Assessment Heavy Metal Pollution in Soil By Various Allied Artisans in Auto-Mechanic Workshop in Osun State, Nigeria. EJEAFChe, 10 (2): $1881-1886$

Olofin E.A (1987): Some Aspect of Physical Geography of Kano Region: Departmental of Geography Lecture Series BUK: Dabis Standard Printers 73A, Zaria Road Kano.

Sorana, D. B., Lorentz, J. (2008): Analysis of Soil Heavy Metal Pollution and Pattern in Central Transylvania. International Journal of Molecular Sciences. 32, 1346 - 1353

Tahar, K and Keltou B. (2011), Effect of heavy metals pollution in soil and plant in industrial Areas, West Algeria. Journal of Korean chemical society. Vo.. 55, No. 6

Yusuf, A. A., Arowolo, T. A. And Bamgbose, 0. (2003): Cadmium, Copper and Nickel level in Vegetations From Industrial and Residential Areas of Lagos City, Nigeria. Food chem. Toxicology, 41: 375-378.

Wild, A. (1996), Introduction of Soils and its Environment An introduction, Cambridge University Press; Cambridge.

Zhang, Y., Zhang H. W., Su Z. C and Zhang C G. (2007). Effects of long-term heavy metals stress on farmland soil microbial population, biomass and activity. Med line (NCBI Pub Med). 18(7): 1491-1497. 